\title{
FORMATION OF TASTE FOR PEDAGOGICAL WORK IN THE PR CHINA: PHENOMENA OF SOCIAL PEDAGOGICAL PRACTICE
}

\section{Han Zhanglian ${ }^{1}$ Marakushin Andriy ${ }^{2}$}

DOI: https://doi.org/10.30525/978-9934-571-89-3_26

The issue of the taste for pedagogical work formation when it concerns representatives of other professions, as well as practicals who gained the qualification in other areas of professional activity, nowadays becomes very relevant. The legislation of many countries by enlisting for educational work people whose professional background is not pedagogical opens the "path to the profession" for those who are already recognized professionals in the non-pedagogical industry, but have a desire to be engaged in teaching activities.

Among the ways that traditionally contribute to the taste for pedagogical activity formation, pedagogical practice occupies the presiding positions. During the pedagogical practice that a person has the opportunity to try himself $\backslash$ herself as a teacher, to understand whether this activity suits himlher, whether helshe has not only the talent, but also the taste to such kind of professional activity. The People's Republic of China professional education system for teachers does not provide students with the opportunity to have pedagogical practice as a form of educational work while they study at university or other high educational institution. Students mainly find the opportunities for passing such practices by themselves for having additional documents for the $\mathrm{CV}$ when graduate.

Social pedagogical practice, as well as pedagogical practice is it, is an integral part of the educational process. It provides a combination of theoretical training of future teachers with their practical activities, promotes creative attitude of a future specialist to pedagogical activity formation, and determines the degree of hislher professional ability and the level of pedagogical orientation. It also helps to consolidate students theoretical and methodological, psychological knowledge of didactics, theory of education, general, age and pedagogical psychology and many other components of pedagogical activity. Social pedagogical practice contributes to students` adaptation to future professional activities, arming their initial experience as a teacher. In the process of passing the practice, a student has the opportunity to observe directly the work of senior colleagues, fulfill their orders, try himselflherself as a teacher, gradually entering the teaching process under the guidance of a mentor [2, p. 4].

Social pedagogical practices in the People's Republic of China are an integral part of the general system of vocational training of teachers and other pedagogical workers. PR China introduced social pedagogical practices as a form of training for pedagogical workers in the late 60's XX cent. Due to the lack of "educators of a new formation who have already received ideological and pedagogical education in the

\footnotetext{
${ }^{1}$ H.S. Skovoroda Kharkiv National Pedagogical University, Ukraine

${ }^{2}$ Kharkiv National University of Economics named after Semen Kuznets, Ukraine
} 
conditions of New China and are free from the misconceptions of previous times" [1, p. 52], graduates and, in some cases, 3rd year students of higher pedagogical courses were actively sent to rural and district schools to practice. The term of the practice was 6 months, but could have been extended at the request of the local authorities due to the objective needs of the school in the countryside. In practice, students worked as teachers and received food and accommodation at the expense of the school in which they were practicing. Almost in all cases the practice automatically turned into job and the student received the diploma externally [4, p. 160]. As the result of revision of teacher training concept in the PR China in the mid 70's XX cent. this practice was abolished due to the "elimination of the Soviet system of education influence and education reforms in the People's Republic of China" [1, p. 67].

Start 1985 due to new Concept of Education in the People's Republic of China certain forms and methods of future teachers` training have been revived. Among the university activities for the students for future educational work in school training were preserved lectures on "Pedagogy" and "Pedagogical skills", collective and individual work with teachers, as well as a personal example of the teacher and the maximum torment of students to the educational activities in the university as the main forms of trainings. Pedagogical practice at schools and other educational institutions was returned to teachers training programs, but as a short-term activity (up to 4 months) in the form of employment of a student as a teacher in a village school. A system of incentives for students who volunteered to provide educational support to first-level institutions (pre-schools and elementary schools) was introduced. This kind of work on a voluntary basis was called "social pedagogical practice" [3, p. 128-129].

Today in the People's Republic of China students, who come to institutions of secondary education to practice pedagogy by their own ("social pedagogical practices"), besides acquiring purely professional skills in teaching lessons, also take part in the educational work of the school. However, their work, to a large extent, is reduced to helping younger teachers to organize current educational process that takes place at school in accordance with the annual "School Work Plan".

Social pedagogical practices are not obligatory when studying in a pedagogical university in China, but are stimulated by a higher educational institution. The noneligibility of any practice is explained by the specifics of the educational process organization in the country in general, in which practice as a form of work is carried out the educational process and is included in the system of acquisition and advanced training at the workplace. In other words, at the university students receive general pedagogical theoretical trainings, and at the first place of work they have to work for one year as a "junior teacher" ("teacher-in-trainings") to gain practical experience and teaching skills.

Since students have the right to conduct social pedagogical practices only and exclusively in their free time (in the system of pedagogical education of the People's Republic of China, there is no opportunity to receive "individual plan of study"), students are mostly socially practiced in the system of informal education for children 
(mini clubs, private courses, private schools, extended-day groups, etc.), in educational institutions and leisure facilities for the elderly, organized by the municipal and public funds, or on Saturday and Sunday during additional classes at public schools. The student has to find a place for the practice by himself $\backslash$ herself, provide a written consent of the school or other organization to the higher education institution, in order the University to provide the student with the characteristics and recommendations for his / her practice. The University supervision is not required, and in any way, does not affect the process of passing a student's social pedagogical practice, but the documents (the characteristic from the institution where the practice was) are attached to the student's personal release, pays a positive influence on the recommendation of the student to study at the next educational levels, distribution of state quotas for jobs, etc. Depending on the specifics of social practice, the student may get a personal tutor (a subject teacher with the same specialization as the student-in-practice) from the school helshe comes to for the social pedagogical practice. A teacher may, depending on the financial level of the school, receive a monetary remuneration from the school, but this is not obligatory, since the presence of the student-in-practice facilitates the work of the teacher with the educational work with students with special educational needs, preparation of additional materials for the lesson, checking homework and written works etc.

Social pedagogical practices in the People's Republic of China are an integral part of the general system of vocational training of teachers and other pedagogical workers. They promote both the acquisition of practical skills and abilities of pedagogical universities`students, as well as the implication of their taste for pedagogical activity, their self-identification as teachers. The People's Republic of China is also interested in the system of social pedagogical practices as almost $95 \%$ of trainers and teachers in the system of clubs for the people of the third age are students of pedagogical universities, working with elderly people on a voluntary basis, as a social pedagogical practice.

\section{References:}

1. Cheng Yuanyuan (2017). Experience of social practice of Pedagogical Universities Students. Changchun University Review, 5, 22-25. (in Chinese)

2. Makarchuk, V. \& Dobryden, A. (2015). Pedagogical practice: educational and methodical manual. Ukraine, Uman: Zhovten.

3. Xie Feiliang (2016). General and theoretical aspects of pedagogical and social practice. Scientific notes of Harbin University, 7, 83-88. (in Chinese)

4. Zhang Long (2014). Dialectics of traditionalism and modernization in China's education system in the era of globalization. Means of training and research work, 42, 157-168. (in Ukrainian) 